\title{
Investigating the Prospect of Copper-Histidine Complex Modified Gold Electrode for Histidine and Human Serum Albumin Recognition
}

1 Irena Kereković

1 Sandra Domjanić Drozdek

1 University of Applied Health Sciences, Department of Chemistry, Biochemistry and Clinical Chemistry, Zagreb, Croatia
Keywords: gold electrode, copper, histidine, human serum albumin, quartz crystal microbalance

Article received: 01.12.2019.

Article accepted: 15.01.2020.

https://doi.org/10.24141/1/6/1/4

\section{Corresponding author:}

Irena Kereković

University of Applied Health Sciences

Department of Chemistry, Biochemistry and Clinical Chemistry Mlinarska cesta 38, Zagreb, Croatia

E-mail: irena.kerekovic@zvu.hr

T: + 385914595984 


\section{Introduction}

Histidine (His) is an essential amino acid for humans ${ }^{1}$ and has a significant role in metabolism and wide range of physiological processes ${ }^{2}$, and measuring His concentration is of outmost importance. Analytical methods have been developed for the determination of histidine, such as chemiluminiscence ${ }^{3}$, high pressure liquid chromatography ${ }^{4}$, capillary electrophoresis ${ }^{5}$, potentiometric $^{6}$, and recently, amperometric ${ }^{7}$ method. However, expensive instrumentation, large sample volumes and use of eco-unfriendly solvents present disadvantages of these techniques.

Human serum albumin (HSA) is the most abundant serum protein ${ }^{8}$. Spectrum of its functions in human physiology ranges from the preservation of the colloid osmotic pressure and binding and transportation of a large number of ligands ${ }^{9}$. Ligands that bind to HSA are of endogenous and exogenous origin such as bilirubin, long chain fatty acids, numerous pharmaceuticals and inorganic ions ${ }^{10}$. One study revealed the catalytic function and pleiotropic properties of $\mathrm{HSA}^{11}$. HSA is used as a therapeutic agent and its primary function is in restoration and maintenance of blood volume in situations that cause blood loss and plasma exchange ${ }^{12}$. Furthermore, it is used as a stabilizing agent in vaccine formulations ${ }^{13}$. Recent studies have demonstrated that HSA binds to variety of organic pollutants and toxins such as triclosan ${ }^{14}$, atrazine ${ }^{15}$, ochratoxins ${ }^{16}$, methyl parathion ${ }^{17}$ and poncean $\mathrm{S}^{18}$, having a significant impact on human health. Methods for determination of HSA concentration have been developed. Routine analysis includes binding to anionic dyes, bromocresol green ${ }^{19}$ and bromocresol green purple ${ }^{20}$, electrophoresis ${ }^{21}$ and spectrophotometric COBAS method ${ }^{22}$. Drawbacks of these methods include eco-unfriendly dyes and expensive instrumentation. Without doubt, investigating binding mechanism of His and HSA to various ligands, as well as improving the measurement techniques, stands out as an important research field in terms of human health.

Adsorption of histidine to the gold surface has been thoroughly investigated. Liedberg et al. ${ }^{23}$ concluded that histidine coordinates to gold over one oxygen of the carboxyl group while Marti et al..$^{24}$ suggested that the both oxygen atoms of the carboxyl group coordinate to gold. Whatever the case, other parts of histidine, i.e. amino group and imidazole nitrogen atom, are avail- able for further metal cation complexation. Research of copper(II)-histidine complexes has been done in detail ${ }^{25-27}$ and the structure was well established. Histidine and $\mathrm{Cu}^{2+}$ cation can form multidentate complexes ${ }^{28-31}$. Coordination number for copper(II)-histidine complex can be 1 or 2 . Higher stability was determined for 2:1 histidine to copper ratio ${ }^{32}$. This capability of $\mathrm{Cu}$-His (1:1) complex to produce a stable complex in coordination with another histidine and human serum albumin was tested in this study.

Quartz crystal microbalance (QCM) is a sensitive weight measuring device based on the piezoelectric effect. Sauerbrey first recognized the possibilities in application of QCM technology ${ }^{33}$ and from then on QCM was used for numerous objectives.

In the present work we investigated the formation of His layer further modified with $\mathrm{Cu}^{2+}$ cation on the surface of the gold electrode (AuQCM/His/ $\mathrm{Cu}^{2+}$ ). Considering that histidine and histidine rich native proteins have a strong affinity to transition metal ions, the binding His and HSA was investigated with QCM on the prepared surface.

\section{Materials and Methods}

\section{Chemicals and solutions}

All the reagents used were of analytical grade. L-histidine (His) and human serum albumin (HSA) were obtained from Sigma-Aldrich (St. Louis, USA). 0.1 M acetate buffer containing $0.1 \mathrm{M}$ sodium perchlorate $\mathrm{pH}=4.6$ (AB) was used. Acetic acid, sodium acetate, copper(II) nitrate and sodium perchlorate were from Kemika ( $\mathrm{Za}$ greb, Croatia). All the solutions were prepared with deaerated double deionized water from Millipore-MilliQ system (USA).

\section{Preparation of AuQCM/His electrode}

$5 \mathrm{mHz}$ AT-cut quartz crystal gold electrode (AuQCM) was purchased from Stanford Research Systems, USA. The electrode was cleaned in ethanol for 5 minutes, rinsed with ultrapure water and then immersed in Piranha solution $\left(\mathrm{V}\left(\mathrm{H}_{2} \mathrm{O}_{2}, 30 \%\right.\right.$.): $\mathrm{V}\left(\mathrm{H}_{2} \mathrm{SO}_{4}\right.$, conc. $\left.)=1: 3\right)$ for 3 minutes. 


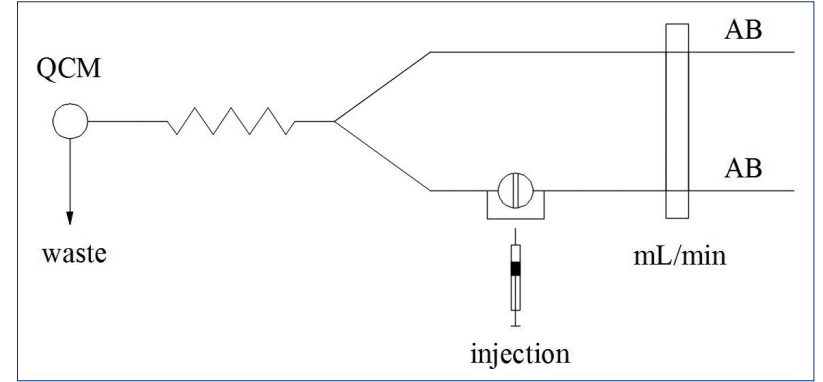

Figure 1.

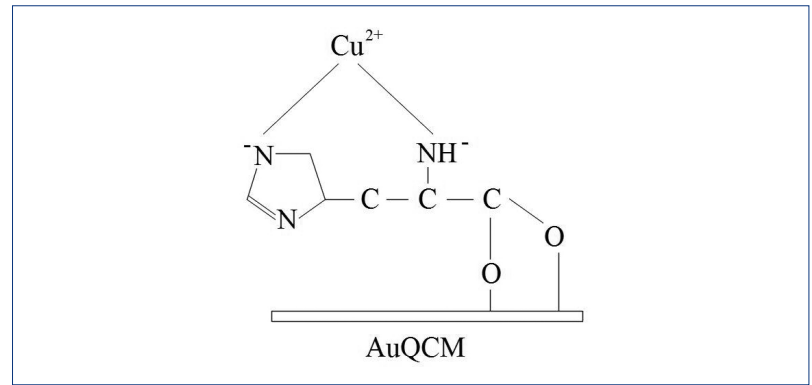

Figure 3.

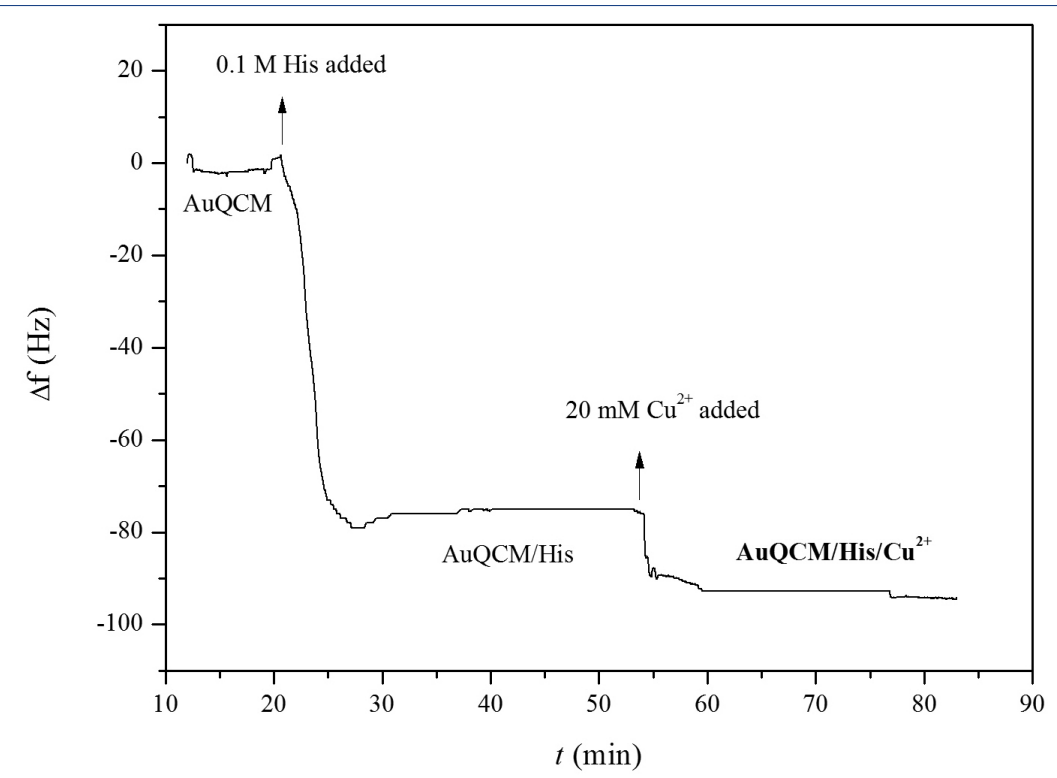

Figure 2 .

Modification of the gold electrode was performed in $100 \mathrm{mM}$ His water solution for approximately 2 hours at room temperature. After removal from His solution the electrode was rinsed with ultrapure water to eliminate physically adsorbed species.

\section{Instrumentation}

Quartz crystal microbalance measurement was performed on Quartz Crystal Digital Controller, QCM200 (Stanford Research Systems, USA) connected to a computer by LabVIEW. QCM measurements were performed in the flow-through system (FIA). Transportation of the carrier solution in FIA mode was made by a double tubing peristaltic pump. Sample injection into carrier stream was done by a syringe using injector valve Rheodyne Model 7125 and the sample loop of $10 \mu \mathrm{L}$ (Figure 1).

\section{Results and Discussion}

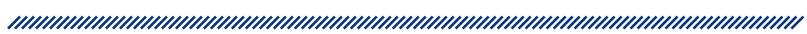

QCM measurements were performed to describe the formation of His layer on the AuQCM electrode. The measurement (Figure 2) was performed on AuQCM gold electrode in $A B$ (base frequency 0 ). Upon injection of 0.1 $M$ His solution the change in frequency $(\sim 80 \mathrm{~Hz})$ is evident. After 10 minutes solution of His in the measuring cell was replaced with $A B$. Thus that final change in the frequency (slightly less than $80 \mathrm{~Hz}$ ) can be attributed to the His adsorbed on the AuQCM electrode. Subsequently $20 \mathrm{mM} \mathrm{Cu}{ }^{2+}$ solution was added and additional $\sim 20$ $\mathrm{Hz}$ change in frequency is obvious (Figure 2). Figure 3 illustrates a possible attachment mode of His to AuQCM surface and complexation with $\mathrm{Cu}^{2+}$ result of which is the formation of $\mathrm{AuQCM} / \mathrm{His} / \mathrm{Cu}^{2+}$ surface modification. 


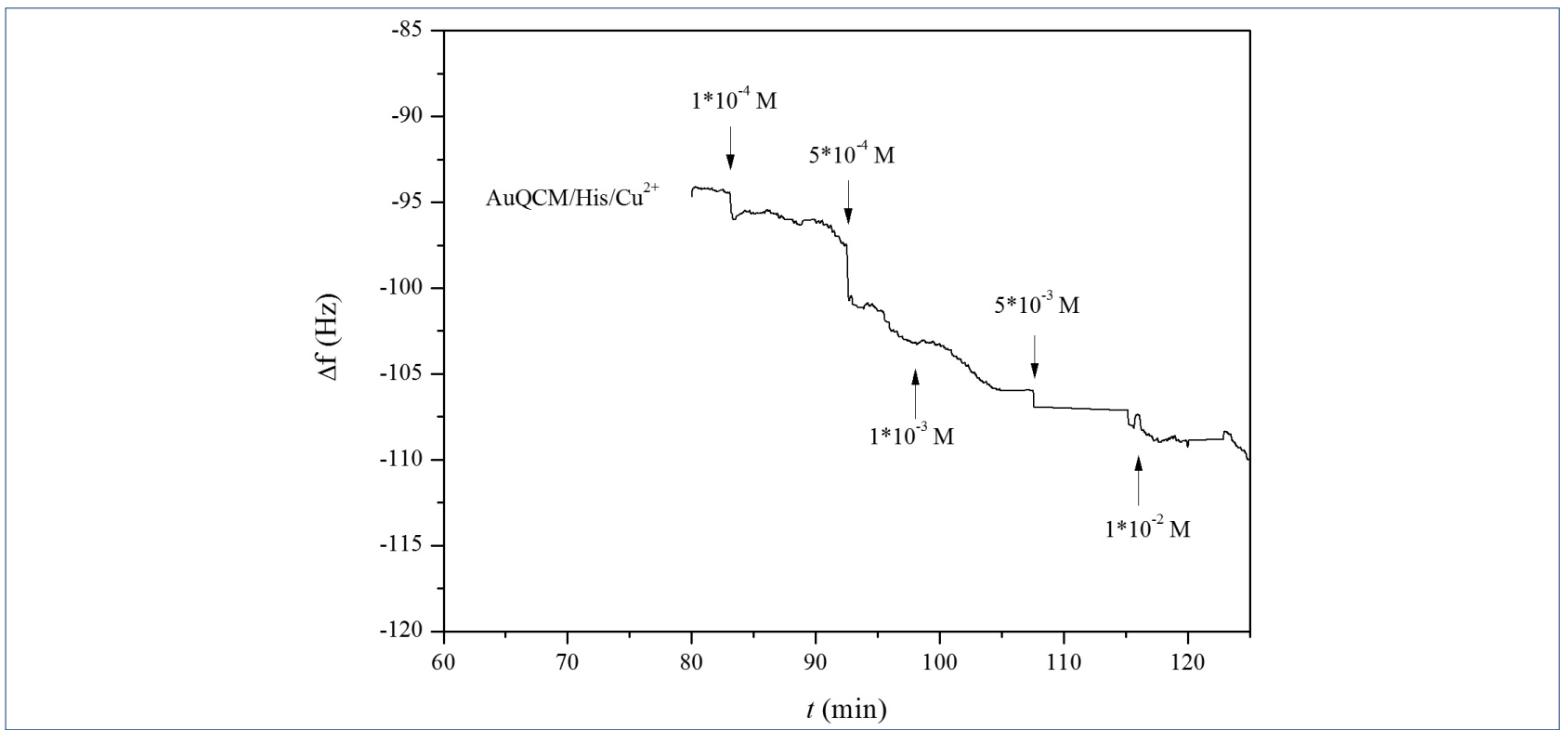

Figure 4.

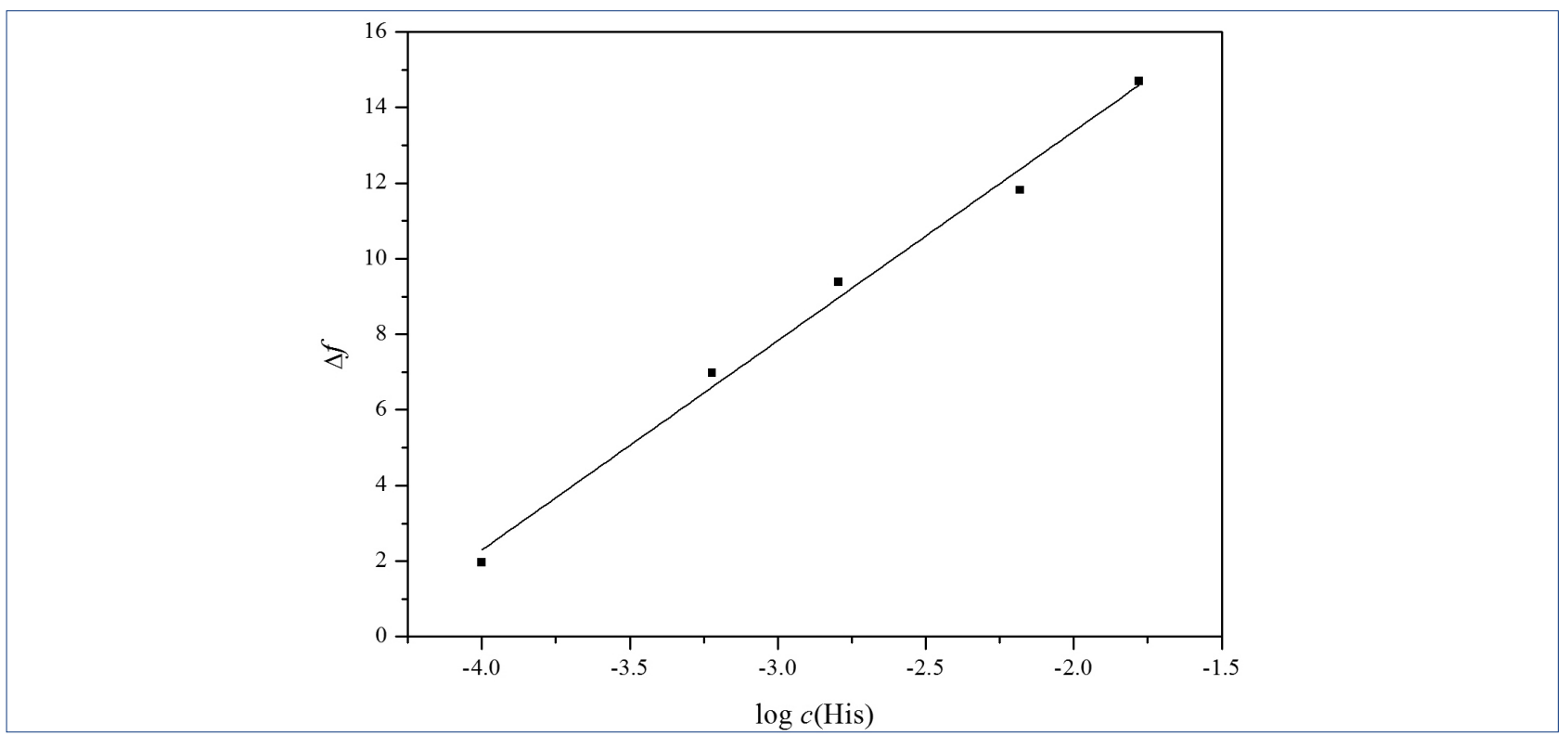

Figure 6.

It has not been established with certainty in which way His adsorbs to gold. If we assume that His binds to gold over both oxygen atoms of the carboxyl group, then $\mathrm{Cu}^{2+}$ can be coordinated with amino group and imidazole nitrogen.

Capability of prepared AuQCM/His/Cu ${ }^{2+}$ electrode for complexation of His was tested in the concentration range from $10^{-4}$ to $10^{-2} \mathrm{M}$. QCM measurements were performed in the flow-through system in a $A B$ at a flow rate of $0.36 \mathrm{~mL} / \mathrm{min}$. Figure 4 illustrates time dependence of frequency change for AuQCM/His/Cu ${ }^{2+}$ electrode after adsorption of His. The time required to rinse the cell, i.e. to stabilize the frequency response for each individual concentration, was approximately 10 minutes. His was adsorbed onto the modified electrode cumulative from minimum to maximum concentration. FIA measurements demonstrated a small change in frequency, about $5 \mathrm{~Hz}$ for every His concentration. Histidine has a small molecular weight $(155.2 \mathrm{~g} / \mathrm{mol})$ and for this reason only a slight change in frequency is evident. From 


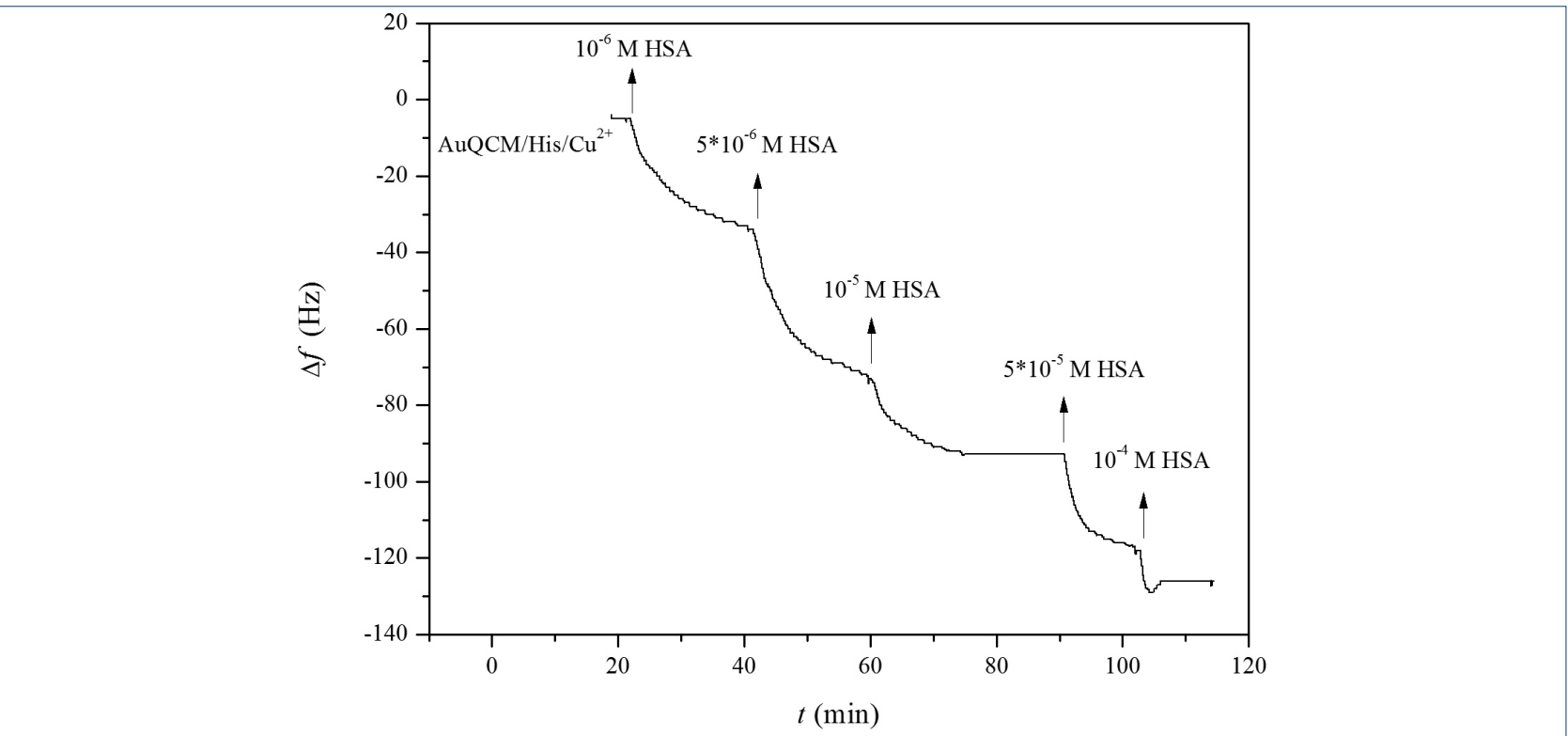

Figure 4.

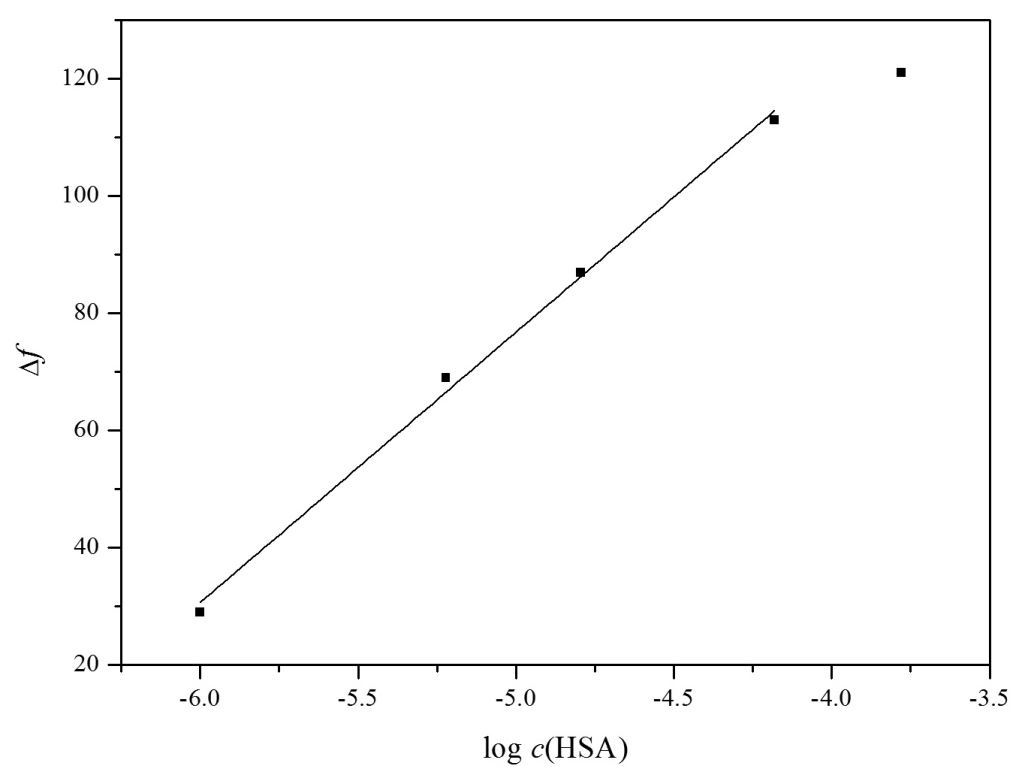

Figure 7.

FIA measurement calibration curve Df vs. $\log \mathrm{c}(\mathrm{His})$ was constructed (Figure 5). The relation between $\Delta f(\Delta f-$ difference between the base AuQCM/His/Cu ${ }^{2+}$ frequency in $A B$ and every individual His addition) and $\log c$ (His) exhibits linear relationship and can be described by regression equation and correlation coefficient: $\Delta f=$ $(24.44 \pm 0.82)+(5.54 \pm 0.28) \cdot \log c(\mathrm{His}), \mathrm{R}^{2}=0.9895$. Stability constant for $\mathrm{Cu}$-His complex is $\mathrm{p} K_{\mathrm{a}}=10.1^{32}$ and for His-Cu-His is $\mathrm{pK}_{\mathrm{a}}=17.5^{32}$ which means that the second complex is more stable hence the response (Figure 4 ) is due to adsorption of His onto the AuQCM/His/ $\mathrm{Cu}^{2+}$ modified electrode. Furthermore, the ability of prepared $\mathrm{Au}$ $\mathrm{QCM} / \mathrm{His} / \mathrm{Cu}^{2+}$ electrode for HSA complexation was tested in the concentration range from $10^{-6}$ to $10^{-4} \mathrm{M}$. The measurement setup was the same as for His adsorption. Figure 6 displays time dependence of frequency change for $\mathrm{AuQCM} / \mathrm{His} / \mathrm{Cu}^{2+}$ electrode after adsorption of HSA. The time required to rinse the cell i.e. to stabilize the frequency response for each individual concentration was approximately $30 \mathrm{~min}$. HSA was adsorbed onto 
the modified electrode cumulative from minimum to maximum concentration. FIA measurements demonstrated a significant change in frequency, about $30 \mathrm{~Hz}$ for every individual HSA concentration. Human serum albumin is a molecule with large molecular weight ( 67 $\mathrm{kDa}$ ) hence substantial change in frequency is obvious. Slow binding kinetics is manifested which as well can be explained with bulky protein structure and large molecular weight. From FIA measurement calibration curve Df vs. $\log c$ (His) was constructed (Figure 7). Relation between $\Delta f(\Delta f$ - difference between the base Au$\mathrm{QCM} / \mathrm{His} / \mathrm{Cu}^{2+}$ frequency in $\mathrm{AB}$ and every individual HSA addition) and $\log C(\mathrm{HSA})$ exhibits linear relationship and can be described by regression equation and correlation coefficient: $\Delta f=(307.35 \pm 9.39)+(46.11 \pm 1.84)$ - $\log c(H S A), R^{2}=0.9952$. Because His-Cu-HSA complex is considerably stable than Cu-HSA (pK (His-Cu-HSA) = $\left.21,74, \mathrm{pK}(\mathrm{Cu}-\mathrm{HSA})=15,54^{34}\right)$ it can be concluded that the response (Figure 6) was the result of HSA adsorption onto the $\mathrm{AuQCM} / \mathrm{His} / \mathrm{Cu}^{2+}$ modified electrode.

\section{Conclusion}

In this research quartz crystal microbalance was used to describe interaction between gold electrode, histidine and $\mathrm{Cu}^{2+}$. QCM was also employed to test the capability of the prepared modified electrode for His and HSA complexation. Complexes of transition metals with amino acids in proteins and peptides are utilized in numerous biological processes. This principle has been a model for the development of sensor for histidine and human serum albumin. Complex matrices which could be examined, like human blood or saliva, contain numerous interferents might need preparation of the sample (dilution, precipitation, filtration or centrifugation) to achieve necessary selectivity and sensitivity. The study in real samples is yet to be carried out but the proof-of-principle has been demonstrated.

\section{References}

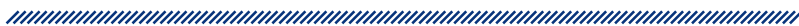

1. Kopple JD, Swendseid ME. Evidence that histidine is an essential amino acid in normal and chronically uremic man. J Clin Invest. 1975; 55(5):881-891. DOI:10.1172/jci108016

2. Stifel FB, Herman RH. Histidine metabolism. Am J Clin Nutr. 1971; 24(2): 207-217. DOI:10.1093/ajcn/24.2.207

3. Kiba N, Koga A, Tachibana M, Tani K, Koizumi H, Koyama T, Yamamura A, Matsumoto K, Okuda T, Yokotsuka $\mathrm{K}$. Flow-injection determination of L-histidine with an immobilized histidine oxidase from Brevibacillus borstelensis KAIT-B-022 and chemiluminescence detection. Anal Sci. 2006; 22(1): 95-98. DOI:10.2116/analsci.22.95

4. Yoshida H, Ichinose F, Yoshitake T, Nakano Y, Todoroki $\mathrm{K}$, Nohta H, Yamaguchi M. Simultaneous determination of histamine and histidine by liquid chromatography following intramolecular excimer-forming fluorescence derivatization with pyrene-labeling reagent. Anal Sci. 2004; 20(3): 557-559. DOI:10.2116/analsci.20.557

5. Osako K, Kurokawa T, Kuwahara K, Nozaki Y. Seasonal variations in taurine and histidine levels of horse mackerel caught in the East China Sea. Fish Sci. 2004; 70: 1180-1182. https://www.jstage.jst.go.jp/article/fishsci1994/70/6/70_6_1180

6. Staden R, Holo L. Enantioselective, potentiometric membrane electrodes based on cyclodextrins for the determination of L-histidineSens. Actuator B-Chem. 2007; 120(2): 399-402. DOI: 10.1016/j.snb.2006.02.033

7. Chen LC, Chang CC, Chang HC. Electrochemical oxidation of histidine at an anodic oxidized boron-doped diamond electrode in neutral solution. Electrochim Acta. 2008; 53(6): 2883-2889. DOI: 10.1016/j.electacta.2007.10.071

8. Bhattacharya AA, Grüne T, Curry S. Crystallographic analysis reveals common modes of binding of medium and long-chain fatty acids to human serum albumin. J Mol Biol. 2000; 303(5): 721-732. DOI: 10.1006/jmbi.2000.4158

9. He XM, Carter DC. Atomic structure and chemistry of human serum albumin. Nature. 1992; 358: 209-215. DOI: $10.1038 / 358209 \mathrm{a0}$

10. Kragh-Hansen U. Molecular aspects of ligand binding to serum albumin. Pharmacol Rev. 1981; 33(1):17-53. http://pharmrev.aspetjournals.org/content/33/1/17/ tab-e-letters

11. Ha C-E, Bhagavan NV. Novel insights into the pleiotropic effects of human serum albumin in health and disease. Bba-Gen Subjects. 2013; 1830(12):5486-5493. DOI: 10.1016/j.bbagen.2013.04.012

12. Matejtschuk P, Dash CH, Gascoigne EW. Production of human albumin solution: a continually developing colloid. Br J Anaesth. 2001; 86(2):301. DOI:10.1093/bja/85.6.887

13. ChuangVT, Kragh-Hansen U, Otagiri M. Pharmaceutical strategies utilizing recombinant human serum albumin. Pharm Res. 2002; 19(5):569-577. DOI:10.1023/a:1015396825274 
14. Chen J, Zhou X, Zhang Y, Zi Y, Qian Y, Gao H, Lin S. Binding of triclosan to human serum albumin: insight into the molecular toxicity of emerging contaminant. Environ Sci Pollut Res. 2012; 19(7): 2528-2536. DOI: 10.1007/s11356012-0901-5

15. Purcell M, Neault JF, Malonga H, Arakawa H, Carpentier $\mathrm{R}$, Tajmir-Riahi HA. Interactions of atrazine and 2,4-D with human serum albumin studied by gel and capillary electrophoresis, and FTIR spectroscopy. Bba-Protein Struct M, 2001; 1548(1): 129-138. DOI: 10.1016/S01674838(01)00229-1

16. Il'ichev YV, Perry JL, Simon JD. Interaction of Ochratoxin A with Human Serum Albumin. Preferential Binding of the Dianion and pH Effects. J Phys Chem B. 2002; 106(2) :452-459. DOI: 10.1021/jp012314u

17. Silva D, Cortez CM, Cunha-Bastos J, Louro SRW. Methyl parathion interaction with human and bovine serum albumin. Toxicol Lett. 2004; 147(1): 53-61. DOI: 10.1016/j. toxlet.2003.10.014

18. Gao H-W, Xu Q, Chen L, Wang S-L, Wang Y, Wu L-L, Yuan Y. Potential Protein Toxicity of Synthetic Pigments: Binding of Poncean S to Human Serum Albumin. Biophys J. 2008; 94(3): 906-917. DOI: 10.1529/biophysj.107.120865

19. Rodkey FL. Direct Spectrophotometric Determination of Albumin in Human Serum Clin Chem. 1965; 11(4): 478-487.

20. Pinnell A, Northam B. New automated dye-binding method for serum albumin determination with bromcresol purple. Clin Chem, 1978; 24(1): 80-86.

21. Hutterer K, Dolník V. Capillary electrophoresis of proteins 2001-2003. Electrophoresis. 2003; 24(22-23): 39984012. DOI:10.1002/elps.200305635

22. Bar-Or D, Lau E, Winkler JV. A novel assay for cobalt-albumin binding and its potential as a marker for myocardial ischemia-a preliminary report. J Emerg Med. 2000; 19(4): 311-315. DOI:10.1016/s0736-4679(00)00255-9

23. Liedberg B, Carlsson C, Lundström I. An infrared reflection-absorption study of amino acids adsorbed on metal surfaces: L-histidine and L-phenylalanine on gold and copper. J Colloid Interface Sci, 1987; 120(1): 64-75. DOI:10.1016/0021-9797(87)90323-7

24. Marti EM, Quash A, Methivier C, Dubot P, Pradier CM. Interaction of S-histidine, an amino acid, with copper and gold surfaces, a comparison based on RAIRS analyses. Colloid Surf A-Physicochem Eng Asp. 2004; 249(1-3):8589. DOI: 10.1016/j.colsurfa.2004.08.055
25. Osz K, Várnagy K, Süli-Vargha H, Csámpay A, Sanna D, Micera G, Sóvágó I. Acid-base properties and copper(II) complexes of dipeptides containing histidine and additional chelating bis(imidazol-2-yl) residues. J Inorg Biochem. 2004; 98(1): 24-32. DOI:10.1016/j.jinorgbio.2003.09.009

26. Jakab IN, Hernadi K, Méhn D, Kollár T, Pálinkó I. Anchoring copper-amino acid complexes on silica or in montmorillonite-an FT-IR study. J Mol Struct. 2003; 651-653:109-114. DOI:10.1016/S0022-2860(03)00101-7

27. Patel VK, Bhattacharya PK. Study of copper(II) ternary complexes involving tertiary amines and histidine. Inorg Chim A. 1984; 92(3):199-201. DOI: 10.1016/S00201693(00)87759-2

28. Krogh-Jespersen K, Westbrook JD, Potenza JA, Schugar HJ. Molecular and electronic structure of (L-histidinato)pentammineruthenium(III) chloride monohydrate, $\left(\mathrm{H}_{3} \mathrm{~N}\right)_{5} \mathrm{Ru}^{\prime \prime \prime}($ his $) \mathrm{Cl}_{3} \cdot \mathrm{H}_{2} \mathrm{O}$. X-ray structure, single-crystal polarized charge-transfer spectra, and ab initio and semiempirical molecular orbital calculations. J Am Chem Soc. 1987; 109(23): 7025-7031. DOI: 10.1021/ja00257a020

29. Evertsson B. The crystal structure of bis-L-histidinecopper(II) dinitrate dehydrate. Acta Crystallogr B. 1969; 25(1): 30-41. DOI:10.1107/S0567740869001737

30. Baidina IA, Slyudkin OP, Borisov SV. Crystal structure of dichloro-L-histidinepalladium(II). J Struct Chem. 1990; 31(3): 503-506. DOI:10.1007/BF00743601

31. Czernuszewicz RS, Yan Q, Bond MR, Carrano CJ. Origin of the Unusual Bending Distortion in the (.mu.-Oxo divanadium(III) Complex [V2O(l-his)4]: A Reinvestigation. Inorg Chem, 1994; 33(26): 6116-6119. DOI: 10.1021/ ic00104a021

32. Deschamps P, Kulkarni PP, Gautam-Basak M, Sarkar B. The saga of copper(II)-L-histidine. Coord Chem Rev. 2005; 249(9-10): 895-909. DOI: 10.1016/j.ccr.2004.09.013

33. Sauerbrey G. Verwendung von Schwingquarzen zur Wägung dünner Schichten und zur Mikrowägung. Z Phys. 1959; 155(2):206-222. DOI:10.1007/BF01337937

34. Lau SJ, Sarkar B. Ternary Coordination Complex between Human Serum Albumin, Copper (II), and L-Histidine J Biol Chem. 1971; 246(19): 5938-5943. http://www.jbc. org/content/246/19/5938 


\section{ZLATNA ELEKTRODA MODIFICIRANA KOMPLEKSOM BAKAR-HISTIDIN KAO MOGUĆA SENZORSKA POVRŠINA ZA PREPOZNAVANJE HISTIDINA I HUMANOG ALBUMINA}

\section{Sažetak}

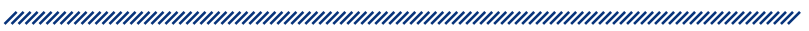

Histidinski monosloj adsorbiran je na zlatnu elektrodu i dalje modificiran kationom $\mathrm{Cu}^{2+}$. Cilj je bio istražiti vezanje histidina (His) i humanog albumina (HSA) na tako pripremljenu površinu. Formiranje sloja na površini zlatne elektrode potvrđeno je kvarcnom mikrovagom. Vezanje histidina i humanog albumina na modificiranu elektrodu uspješno je izvršeno za širok raspon ispitivanih koncentracija. Dobiven je odziv linearno proporcionalan koncentraciji histidina i humanog albumina s koeficijentom korelacije $\mathrm{R}^{2}=0,9895$ odnosno $\mathrm{R}^{2}=0,9952$. 